\title{
HLA Antigen Status and Outcome of Postoperative Adjuvant Immunochemotherapy in Gastric Cancer ; A Multidimensional Data Analysis
}

\author{
ORIGINAL ARTICLE Annals of Cancer Research and Therapy
}

Kyoji Ogoshi • Toshio Mitomi"1), Kimiyoshi Tsuji"2), and Chikio Hayashi ${ }^{* 3)}$

We investigated whether HLA antigens could act as predictors of the response to therapy in gastric cancer.

The microcytotoxicity assay was used to examine HLA antigens of the A, B, and C loci in 429 patients who underwent gastric cancer resection. HLA antigens were then divided four categories after quantifying the response pattern. To evaluate the prognostic factors, multivariate analysis using Cox's model was performed in 321 patients using seven variables : sex, age, pTNM stage, postoperative adjuvant therapy, HLA category, and the association of HLA category with the response to postoperative therapy. Patients received either gastrectomy alone, gastrectomy plus chemotherapy, or gastrectomy plus PSK \pm chemotherapy. The Cox's analysis indicated that HLA Category 4 patients receiving PSK \pm chemotherapy had a better prognosis than those of HLA categories 1,3 , and 4 receiving gastrectomy alone or those of HLA category 1 receiving chemotherapy after gastrectomy.

These results suggest that HLA antigen status can predict the response to therapy and that rational individualized therapy for cancer patients may possibly be designed in the future by evaluating HLA antigens.

Ann Cancer Res Ther 2 (1) : 95-99, 1993 / Received 5 Mar 1993

Key words : HLA antigens, gastric cancer, postoperative adjuvant immunochemotherapy, PSK, third quantification method

If it was possible to predict rational or effective forms of individualized therapy for cancer patients before treatment, they should gain both an improved "quality of life" and a better therapeutic outcome. Our strategy of studying the associations between HLA antigens and the effectiveness of postoperative adjuvant therapy is a novel approach to the detection of parameters for making such predictions.

In Japan, gastric cancer appears to be sensitive to chemotherapy $^{1)}$, but this is not so in the West ${ }^{2)}$. Japanese studies also show a better survival rate for gastric cancer than that found in the West ${ }^{3}$.

Postoperative adjuvant immunochemotherapy and chemotherapy have been reported to be effective against gastric $^{4,5)}$ and colon cancer ${ }^{(5)}$ in Japan and against colon cancer in the the USA ${ }^{7)}$. Mitomycin C (MMC), fluoropyrimidines, the protein-bound polysaccharide PSK (Krestin), and levamisole have all been used as chemotherapeutic or immunomodulating agents. However, why a response is obtained to postoperative adjuvant therapy have not yet been sufficiently evaluated.

PSK is a nonspecific immunoptentiator that is widely prescribed by the oral route in Japan. It is extracted from Coriolus vesicolor (Fr.) Quel, a member of the Basidiomycetes, is composed of both proteins and

\footnotetext{
*1) Department of Surgery, *2) Department of Transplantation Immunology, Tokai University, School of Medicine, Kanagawa *3), Institute of Statistical Mathematics, Tokyo, Japan
}

polysaccharides, and has a molecular weight of approximately 100,000 . An antitumor acivity of PSK has been demonstrated in experimental animal models ${ }^{8}$. 9), and a beneficial therapeutic effects has been noted in clinical studies of esophageal ${ }^{10)}$, gastric, and colon cancer.

In this study, we classified the subjects according to the theory of quantification of response ${ }^{11,13)}$. Then we retrospectively studied the association between the HLA antigen status of gastric cancer patient, and the effect of postoperative adjuvant therapy on survival.

\section{Materials and methods}

From June 1979 to June 1990, HLA antigens of the A, $B$, and $C$ loci were examined preoperatively in 429 patients with histologically confirmed adenocarcinoma of the stomach using the standard lymphocyte microcytotoxicity assay ${ }^{12)}$. Their ages ranged from 22 to 93 years (median : 57.6 years), and $67.4 \%$ were men. Tissue typing was performed for the following antigens : A loci-1, 2, 3, 9, 10, 11, w19, 24, 26, 31, w33 ; B loci-5, $7,12,13,15,16,17$, w22, 27, 35, 37, 39, 40, 44, w46, w48, 51, w52, w54, w55, w56, w59, w60, w61, w62, w67; and Cloci-w1, w3, w4, and w7.

To explore relationships among the HLA antigens, a factor analysis method was applied. Patients were categorized based on the theory of quantification of the response pattern (third quantification method ${ }^{13)}$ ), which is equivalent to the correspondence analysis method of 
Table 1 Clinical profile of the different treatment groups

\begin{tabular}{|c|c|c|c|c|}
\hline & GA & $\mathrm{CT}$ & PSK & Total \\
\hline \multicolumn{5}{|l|}{ Sex } \\
\hline Female & 22 & 36 & 43 & 101 \\
\hline Male & 68 & 62 & 90 & 220 \\
\hline \multicolumn{5}{|l|}{ Age } \\
\hline-49 & 21 & 35 & 33 & 89 \\
\hline $50-59$ & 21 & 25 & 44 & 90 \\
\hline $60-69$ & 24 & 21 & 33 & 78 \\
\hline $70-$ & 24 & 17 & 23 & 64 \\
\hline \multicolumn{5}{|l|}{ Stage } \\
\hline $1 \mathrm{~A}$ & 71 & 16 & 67 & 154 \\
\hline $1 \mathrm{~B}$ & 10 & 12 & 17 & 39 \\
\hline 2 & 3 & 18 & 17 & 38 \\
\hline $3 \mathrm{~A}$ & 0 & 15 & 10 & 25 \\
\hline $3 B$ & 0 & 5 & 6 & 11 \\
\hline 4 & 6 & 32 & 16 & 54 \\
\hline \multicolumn{5}{|l|}{ Category } \\
\hline I & 13 & 17 & 21 & 51 \\
\hline II & 10 & 12 & 20 & 42 \\
\hline III & 43 & 41 & 52 & 136 \\
\hline $\mathrm{IV}$ & 24 & 28 & 40 & 92 \\
\hline
\end{tabular}

PSK : gastrectomy + PSK \pm chemotherapy

CT : gastrectomy + chemotherapy

GA : gastrectomy

Benzeri ${ }^{14)}$. Multivariate analysis using Cox's model was performed with seven variables : sex, age, pTNM stage, postoperative therapy, HLA category, and the association of HLA category with the response to postoperative therapies. Of the 429 gastric cancer patients, 321 received either gastrectomy, gastrectomy with chemotherapy, or gastrectomy with PSK \pm chemotherapy, while 108 received gastrectomy plus treatment with various other chemotherapeutic or immunomodulating agents. A total of 321 patients were evaluated for prognosis by multivariate analysis. The treatment plan and the use of chemotherapy were left up to the judgment of the attending doctors. A clinical profile of the 321 patients is shown in Table 1 .

Ninety patients received only gastrectomy, 98 had gastrectomy plus chemotherapy, and 133 had gastrectomy plus PSK (Kureha Chemical Industry Co. Ltd., Tokyo, Japan) \pm chemotherapy. Postoperative adjuvant chemotherapy was started with then intravenous administration of mitomycin C (MMC) (Kyowa Hakko Kogyo Co. Ltd., Tokyo, Japan) (20 mg intraoperatively and $10 \mathrm{mg}$ on postoperative day 1). This was followed on postoperative day 14 with the oral administration of fluoropyrimidines, such as N1-(2'tetrahydrofuryl)-5-fluorouracil (Futraful) (Taiho Pharmaceutical Co Ltd., Tokyo, Japan) at $600 \mathrm{mg} /$ day or or 5-fluorouracil (5-FU) (Kyowa Hakko Kogyo Co Ltd, Tokyo, Japan) at $150 \mathrm{mg} /$ day. Of these 98 patients, 19 received MMC alone, 14 received fluoropyrimidines alone, and 65 received MMC plus fluoropyrimidines.

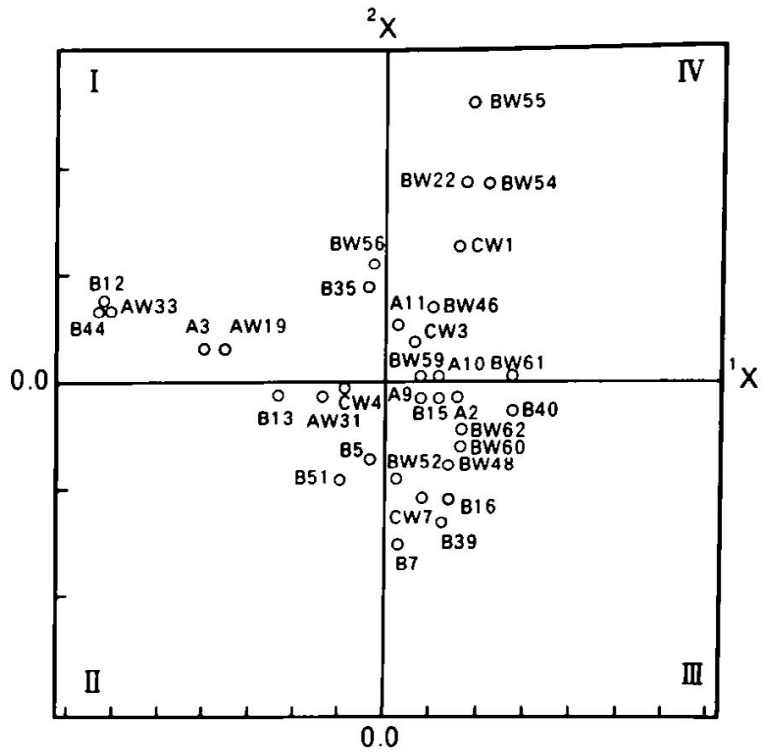

Fig.1 The four categories of HLA antigens

Sixty-five patients received PSK ( $3.0 \mathrm{~g} /$ day) alone starting on POD 14 after gastrectomy, and 68 received postoperative adjuvant chemotherapy plus PSK. The chemotherapy given with PSK was as follows : 2 patients received MMC alone, 14 received fluoropyrimidines alone, and 52 received MMC plus fluoropyrimidines. Fluoropyrimidines or PSK were administered orally over a period of 3 months.

All resected tumor specimens were subjected to detailed pathological examination, and the patients were then staged according to the 1987 pTNM staging of the UICC.

Survival was assessed from the day of surgery until death. Follow-up information was obtained by outpatient appointment or telephone contact with the patients themselves or their families. The 2-, 3-, 5-, and 10-year follow-up rates were $100.0 \%, 66.0 \%, 42.7 \%$ and $33.3 \%$, respectively. Statistical analysis was carried out using the SAS software.

\section{Results}

Seven HLA antigens could not be evaluated : the sample size was too small for A-1, A-26, B-17, B-27, B37 and B-67, while A-24 was not evaluated because of it corresponds to A-9. The remaining 34 HLA antigens were classified into the following four categories using the quantification of response pattern : Category I (A3, Aw-19, Aw-33, B-12, B-44, Bw-56, B-35), category II (Aw-31, B-5, B-51, B-13, Cw-4), category III (A-2, A-9, Bw-52, B-7, B-15, Bw-62, B-16, B-39, B-40, Bw$60, \mathrm{Bw}-48, \mathrm{Cw}-7)$, and category $\mathrm{N}(\mathrm{A}-10, \mathrm{~A}-11, \mathrm{Bw}-22$, Bw-54, Bw-55, Bw-61, Bw-46, Bw-59, Cw-1, Cw-3) (Fig.1). 
Table 2 Univariate analysis in 321 gastric cancer patients

\begin{tabular}{|c|c|c|c|c|}
\hline Variable & $\begin{array}{l}\text { Parameter } \\
\text { estimate }\end{array}$ & $\begin{array}{l}\text { Chi- } \\
\text { squared } \\
\text { test }\end{array}$ & $\begin{array}{l}\mathrm{p} \\
\text { value }\end{array}$ & $\begin{array}{l}\text { Risk } \\
\text { ratio }\end{array}$ \\
\hline \multicolumn{5}{|l|}{ Sex } \\
\hline Female & 0 & & & 1 \\
\hline Male & 0.062949 & 0.05836 & NS & 1.065 \\
\hline \multicolumn{5}{|l|}{ Age } \\
\hline-49 & 0 & & & 1 \\
\hline $50-59$ & 0.502040 & 1.89398 & NS & 1.652 \\
\hline $60-69$ & 0.954591 & 5.95895 & 0.0146 & 2.598 \\
\hline 70 & 1.441960 & 16.24727 & $>0.0001$ & 4.229 \\
\hline \multicolumn{5}{|l|}{ Stage } \\
\hline $1 \mathrm{~A}$ & 0 & & & 1 \\
\hline IB & 0.831285 & 2.30323 & NS & 2.296 \\
\hline 2 & 1.455448 & 8.68176 & 0.0032 & 4.286 \\
\hline $3 A$ & 2.149307 & 16.72218 & $>0.0001$ & 8.579 \\
\hline $3 B$ & 2.662640 & 13.56041 & 0.0002 & 14.334 \\
\hline 4 & 4.166280 & 88.80954 & $>0.0001$ & 64.475 \\
\hline \multicolumn{5}{|l|}{ Therapy } \\
\hline PSK & 0 & & & 1 \\
\hline $\mathrm{CT}$ & 0.316713 & 1.23694 & NS & 1.373 \\
\hline GA & 1.146060 & 9.23476 & 0.0024 & 3.146 \\
\hline \multicolumn{5}{|l|}{ Category } \\
\hline III & 0 & & & 1 \\
\hline N & 0.476069 & 2.90970 & NS & 1.610 \\
\hline II & 0.488028 & 1.49277 & NS & 1.629 \\
\hline I & 0.972067 & 8.68125 & 0.0032 & 2.643 \\
\hline \multicolumn{5}{|c|}{$N S: P>0.05$} \\
\hline \multicolumn{5}{|c|}{$\begin{array}{l}\text { PSK : gastrectomy + PSK Jchemotherapy } \\
\text { CT : gastrectomy + chemotherapy } \\
\text { GA : gastrectomy }\end{array}$} \\
\hline
\end{tabular}

Table 2 shows the results of univariate analysis of maximum likelihood estimates. Patients treated with PSK \pm chemotherapy after gastrectomy showed a significantly better outcome than those receiving gastrectomy alone. In addition, patients in HLA category III showed a significantly better outcome than those in HLA category I.

Table 3 shows the results of multivariate analysis of the factors influencing the survival of patients after gastrectomy alone, gastrectomy plus chemotherapy, or gastrectomy plus PSK \pm chemotherapy. The gastrectomy plus PSK \pm chemotherapy patients in HLA category IV showed significantly better results than gastrectomy patients of HLA categories I, III and IV or gastrectomy plus chemotherapy patients of category I .

\section{Discussion}

Evaluation of parameters that are correlated with the response to treatment would allow the more rational or suitable use of cancer therapy.

For example, we have previously found that gastric cancer patients with abnormal pretreatment sialic acid levels showed a better response when they were given PSK in combination with chemotherapy ${ }^{15}$, while
Table 3 Multiple variate analysis by Cox's model in 321 gastric cancer patients

\begin{tabular}{|c|c|c|c|c|}
\hline Variable & $\begin{array}{l}\text { Parameter } \\
\text { Estimate }\end{array}$ & $\begin{array}{l}\text { Chi- } \\
\text { squared } \\
\text { test }\end{array}$ & $\begin{array}{l}p \\
\text { value }\end{array}$ & $\begin{array}{l}\text { Risk } \\
\text { ratio }\end{array}$ \\
\hline \multicolumn{5}{|l|}{$\operatorname{Sex}$} \\
\hline Female & 0 & & & 1 \\
\hline Male & 0.028669 & 0.01163 & NS & 1.029 \\
\hline \multicolumn{5}{|l|}{ Age } \\
\hline-49 & 0 & & & 1 \\
\hline $50-59$ & 0.476537 & 1.67428 & NS & 1.610 \\
\hline $60-69$ & 0.919181 & 5.48559 & 0.0192 & 2.507 \\
\hline $70-$ & 1.472195 & 16.44272 & $>0.0001$ & 4.359 \\
\hline \multicolumn{5}{|l|}{ Stage } \\
\hline IA & 0 & & & 1 \\
\hline IB & 0.891210 & 2.59558 & NS & 2.438 \\
\hline 2 & 1.452635 & 8.26260 & 0.0040 & 4.274 \\
\hline $3 \mathrm{~A}$ & 2.217470 & 17.15558 & $>0.0001$ & 9.184 \\
\hline $3 \mathrm{~B}$ & 2.594512 & 12.26014 & 0.0005 & 13.390 \\
\hline 4 & 4.129570 & 86.17772 & $>0.0001$ & 62.151 \\
\hline \multicolumn{5}{|l|}{ Therapy } \\
\hline \multicolumn{5}{|l|}{ \& Category } \\
\hline IV \& PSK & 0 & & & 1 \\
\hline II \& PSK & 0.103809 & 0.02951 & NS & 1.109 \\
\hline II \& CT & 0.159352 & 0.08222 & NS & 1.173 \\
\hline II \& CT & 0.545904 & 0.62807 & NS & 1.726 \\
\hline II \& PSK & 0.750140 & 1.15924 & NS & 2.117 \\
\hline$N \& C T$ & 0.978159 & 3.19342 & NS & 2.660 \\
\hline I \& PSK & 1.024997 & 2.41072 & NS & 2.787 \\
\hline III \& GA & 1.185294 & 4.01960 & 0.0450 & 3.272 \\
\hline I \& CT & 1.206693 & 4.23839 & 0.0395 & 3.342 \\
\hline II $\& \mathrm{GA}$ & 1.432099 & 1.55132 & NS & 4.187 \\
\hline$N \& G A$ & 1.433725 & 4.13607 & 0.0420 & 4.194 \\
\hline I \& GA & 2.005852 & 6.25254 & 0.0124 & 7.432 \\
\hline
\end{tabular}

NS : $P>0.05$

PSK : gastrectomy + PSK \pm chemotherapy

$\mathrm{CT}$ : gastrectomy + chemotherapy

$\mathrm{GA}$ : gastrectomy

patients with abnormal levels of immunosuppressive acidic protein showed a better response, when they were given PSK in combination with chemotherapy after total gastrectomy and splenectomy than those with normal levels ${ }^{16)}$. Therefore, it seems that the levels of acute phase reactants such as sialic acid and immunosuppressive acidic protein may predict the effectiveness of immunotherapy using PSK.

However, such predictors do not allow us to select individualized therapy for a single patient, i.e., we cannot assure each cancer patient that the therapy being offered is rational and will achieve a good result. Because each individual has a unique HLA type, we selected HLA antigen status for investigation in the present study.

PSK may induce its antitumor effect by promoting interferon and interleukin-2 production ${ }^{17},{ }^{18}$ ). PSK is also considered to be a potent inducer of gene expression for some interleukins (interleukin- $1 \alpha,-\beta,-6,-8$ ), tumor necrosis factor- $\alpha$, and monocyte chemotactic and activating factor ${ }^{19)}$. Thus, the antitumor activity of PSK 
probably depends on its regulation of host immunity and its ability to normalize the immunosuppressed state of cancer patients.

Chemotherapy such as adriamycin, MMC and fluoropyrimidines may induce cell-mediated cytotoxicity $^{20,21)}$ and may also promote the production of cytokines such as interleukin, and $\rho$-interferon ${ }^{22,}{ }^{23)}$. Experimental studies have also indicated that the HLA phenotype can influence the immune response ${ }^{24)}$. This may explain why certain HLA antigens appear to correlate with various chemotherapy regimens. Thus, chemotherapy agents as well as immunomodulating agents may influence the host immune response. HLA antigens can be seen as a useful maker for both the immune response and for identification of the characteristics of an individual patient.

It has also been reported that in cell lines negative for HLA-DR expression, HLA-DR synthesis and expression can be induced by $\rho$-interferon ${ }^{25)}$. In addition, tumor cells in biopsy specimens from $\rho$ interferon nonresponders were found to be negative for the expression of DR antigens both before and after treatment. Furthermore, it has been suggested that the HLA-DR antigens expression by tumor cells may play a role in the response to interleukin-2 with or without lymphokine-activated killer cells, and that marked tumor infiltration by $T$ cells accompanies and possibly mediates such a respse ${ }^{26)}$. A recent study demonstrated that major histocompatibility complex (MHC) class Ipositive tumors stimulated autologous lymphocytes more frequently than did class I-negative tumors ${ }^{27}$. In addition, the HLA $B$ locus is adjacent to that for tumor necrosis factor ${ }^{28,29)}$. All these observations suggest that there may be an association between HLA phenotype and the effectiveness of anticancer therapy, especially immunotherapy.

An association between HLA antigens and survival has been reported for gastric cancer, and the expression of HLA DR4 and HLA-DR by tumors is apparently associated with a good prognosis ${ }^{30,31}$.

There have only been a few reports concerning associations between HLA antigens and the effectiveness of anticancer therapy. An association between HLA antigens and the response to immunotherapy was reported by Tursz et al. ${ }^{32}$. They found that long-term survivors of lymphoblastic leukemia who received BCG immunotherapy had a high frequency of HLA Aw33 or B17 compared with healthy controls, but the actual HLA phenotype responding to immunotherapy was not clarified. We have previously reported that gastric cancer patients with HLA-Bw40 antigen showed a good response to PSK combined with chemotherapy ${ }^{33)}$.
Regarding the association between the response to PSK and MHC antigens, Vanky et al. reported that in the presence of PSK, tumor cells with low-class-I-antigenexpression could undergo lysis by lymphocytes, and suggested that PSK potentiated the function of antigenspecific lymphocytes but did not generate such cells ${ }^{34)}$.

We used the quantification of response method to classify HLA antigens associated with a similar response to therapy. This method has usually has been utilized for classification of data, e,g, in surveys of national characteristics ${ }^{35,36)}$, and is one method of classifying individuals on the basis of similarity of responses to categorical questions. Using this method, the configurations of both the individuals and the categories in a multidimensional Euclidian space is able to provide inferences regarding their categorization.

Using this method, we categorized HLA antigens into four groups and then found that the therapeutic results of gastric cancer patients in different categories had different responses to the various adjuvant therapies.

From the published literature and our results we speculate that the level of MHC expression by lymphocytes is correlated with the response to therapy and that there may be restriction among HLA antigens, $T$ cell receptors, and the PSK receptor. However, we do not have a definite mechanism to propose as yet.

It appears that HLA antigen status should be considered when we treat patients with anticancer therapy. Our findings also emphasize that it is important to consider a patient's genetic constitution when managing malignant disease. It is of obvious benefit to individual patients if we can select those who are likely to respond before initiating therapy. Moreover, HLA typing may lead to clues on the genetic origin of tumor resistance to immunomotherapy and chemotherapy, as well as information on how certain types of drug resistance may be prevented or overcome and on the development of more rational and effective treatment protocols. Thus, the approach of individualizing cancer therapy by HLA typing of patients holds some promise for the future.

\section{References}

1) Inokuchi $K$ : Prolonged survival of gastric cancer patients on a specific adjuvant chemotherapy. Jpn Surg, $14: 351-359,1984$.

2) Allum WH, Hallissey MT, Ward LC, Hockey MS, for the British Stomach Cancer Group : A controlled, prospective, randomized trial of adjuvant chemotherapy or radiotherapy in resectable gastric cancer : interim report. Br J Cancer, 60 : 739-744, 1989.

3) Adam $Y G$, Feron $G$ : Trends and controversies in the management of carcinoma of the stomach. Surg Gynecol Obstet, $169: 371-385$, 1989.

4) Hattori $T$, Inokuchi $K$, Taguchi $T$, Abe $O$ : Postoperative adjuvant chemotherapy for gastric cancer, the second report. Analysis of data on 2873 patients followed for five years. Jpn J Surg, $16: 175-180$. 1986. 
5) Torisu M, Hayashi $Y$, Ishimitsu T, Fujimura T, Iwasaki K, Katano M, Yamamoto H, Kimura $Y$, Takesue $M$, Kondo $M$, Nomoto $K$ : Significant prolongation of disease-free period gained by oral polysaccharide K (PSK) administration after curative surgical operation of colorectal cancer. Cancer Immunol Immunother, 31 : 261-268, 1990.

6) Mitomi T, Tsuchiya S, Iijima N, Aso K, Suzuki K, Nishiyama K, Amano T, Takahashi T, Murayama N, Oka H, Oya K, Noto T, Ogawa $\mathrm{N}$ : Randomized, controlled study on adjuvant immunochemotherapy with PSK in curatively resected colorectal cancer. Dis Colon Rectum, 35: 123-130, 1992.

7) Moertel CG, Fleming TR, Macdonald JS, Haller DG, Laurie JA, Goodman PJ, Ungerleider JS, Emerson WA, Tormey DC, Glick JH, Veeder MH, Mailliard JA : Levamisole and fluorouracil for adjuvant therapy of resected colon carcinoma. N Eng J Med, 322 : 352-358, 1990.

8) Tsukagoshi S, Hashimoto Y, Fujii G, Kobayashi H, Nomoto K, Orita K. Krestin (PSK) : Cancer Treatment Reviews, 11 : 131-155, 1984.

9) Ehrke MJ, Reino JM, Eppolito C, Mihich E : The effect of PS-K, a protein bound polysaccharide, on immune responses against allogeneic antigens. Int J Immunopharmac, 5 : 35-42, 1983.

10) Ogoshi $K$ : The cooperative study group of PSK for esophageal cancer : Evaluation of immunotherapy with PSK for esophageal cancer. Jpn J Cancer Chemother, 15 : 3143-3151, 1988, (Japanese).

11) Hayashi $\mathbf{C}$ : Theory and examples of quantification (II). Proc Inst Statist Math, $4:$ 19-30, 1956.

12) Terasaki PI, Benoco D, Park MS, Ozturk G, Iwaki $Y$ : Microdroplet testing for HLA-A, -B, -C, and -D antigens. A J C P, 69 : 103-120, 1778 .

13) Hayashi C: Quantification Method III or Correspondence Analysis in Medical Science. Ann Cancer Res Ther, 1 : 17-21, 1992.

14) Hayashi $C$ : Response reliability and multidimensional data analysis. In : Bock HH, ed. Classification and related methods of data analysis. Amsterdam, North-Holland : Elsevier Science Publishers B V. 625-632, 1988.

15) Ogoshi K, Kondoh $Y$, Tajima T, Mitomi $T$ : Glycosidically bound sialic acid levels as a predictive marker of postoperative adjuvant therapy in gastric cancer. Cancer Immunol Immunother, $35: 175$ 180, 1992.

16) Ogoshi K, Miyaji M, Iwata $K$, Kondoh $Y$, Tajima $T$, Mitomi $T$. Splenectomy, immunosuppressive acidic protein and postoperative immunotherapy in gastric cancer patients with total or proximal gastrectomy ; a multivariate analysis. Ann Cancer Res Ther, $1: 61$ 66, 1992.

17) Kitami $H$, Tsuru $S$, Oguchi $M$, Watanabe $M$, Zinnaka $Y$ : Effect of PSK in interferon production in tumor-bearing mice. J Clin Lab Immunol, $15: 211-214,1984$.

18) Kikuchi $Y$, Kizawa I, Oomori K, Iwano I, Kita T, Kato K : Effects of PSK on interleukin-2 production by peritoneal lymphocytes of patients with advanced ovarian carcinoma during chemotherapy. Jpn J Cancer Res, 79 : 125-130, 1988.

19) Hirose K, Zachariae COC. Oppenheim JJ, Matsushima K : Induction of gene expression and production of immunomodulating cytokines by PSK in human peripheral blood mononuclear cell. Lymphokine Research, 9 : 475-483, 1990.

20) Orsini F, Pavelic Z, Mihich E : Increased primary cell-mediated immunity in culture subsequent to adriamycin or daunorubicin treatment of spleen donor mice. Cancer Res, 37 : 1719-1726, 1977.

21) Hong WS, Kim CM, Lee JO, Kang TW, Yun TK, Kim CY : Natural killer and lymphokine-activated killer activities in stomach cancer patients with special emphasis on the effect of 5-Fluorouracil, adriamycin and mitomycin-C chemotherapy. Jpn J Clin Oncol, 20 : 87-93, 1990.

22) Cesario TC, Slater LM, Kaplan HS, Gupta S, Gorse GJ : Effect of antineoplastic agents on $\gamma$-intreferon production in human peripheral blood mononuclear cells. Cancer Res, 44 : 4962-4966, 1984.

23) Ehrke MJ, Maccubbin D, Ryoyama K, Cohen SA, Mihich E : Correlation between adriamycin-induced augmentation of interleukin 2 production and of cell-mediated cytotoxicity in mice. Cancer Res, $46: 54-60,1986$.

24) McDevitt HO, Chinitz A : Genetic control of antibody response : Relationship between immune response and histocompatibility $(\mathrm{H}-2)$ type. Science, $163: 1207-1208,1969$.

25) Basham TY, Merigan TC. Recombinant interferon gamma increases HLA DR synthesis and expression. J Immunol, 130 : 1492-1494, 1983.

26) Cohen PJ, Lotze MT, Roberts JR, Rosenberg SA, Jaffe ES : The immunopathology of sequential tumor biopsies in patients treated with interleukin-2. Correlation of response with T-cell infiltration and HLA-DR expression. Am J Pathol, $129: 208-216,1987$.

27) Vanky F, Stuber G, Rotstein $S$, Klein E : Auto-tumor recognition following in vitro induction of $\mathrm{MHC}$ antigen expression on solid human tumors : stimulation of lymphocytes and generation of cytotoxicity against the original MHC-antigen-negative tumor cells. Cancer Immunol Immunother, $28: 17-21,1989$.

28) Spies T, Morton CC, Nedospasvo SA, Fiers W, Pious D, Strominger $\mathrm{JL}$ : Genes for the tumor necrosis factors $\alpha$ and $\beta$ are linked to the human major histocompatibility complex. Proc Natl Acad Sci, 83 : 8699-8702, 1986.

29) Spies T, Blanck G, Bresnahan M, Sands J, Strominger JL : A new cluster of genes within the human major histocompatibility complex. Science, $243: 214-217,1989$.

30) Hayashi R, Ochiai T : HLA type and survival in gastric cancer. Cancer Res, 46 : 3701-3703, 1986.

31) Hitton DA, West KP: An evaluation of the prognostic significance of HLA-DR expression in gastric carcinoma. Cancer, $66: 1154-1157$, 1990.

32) Tursz $T$, Hors J, Lipinski $M$, Mathe $G$ : Hemopoietic and lymphoid neoplasias. 5. Comparison of HLA phenotypes in long-term survivors with acute lymphoblastic leukemia treated with immunotherapy versus chemotherapy. In : Recent results in cancer research. Berlin, Heidelberg : Springer-Verlag, 80:26-28, 1982.

33) Ogoshi K, Mitomi T : Clinical effects of PSK on esophageal and gastric cancer patients and usefulness of serum levels of glycoproteins and HLA antigens as prognostic indicators. J Jpn surg Soc, $90: 1443-1446,1989$, (Japanese).

34) Vanky F, Wang P, Klein E : The polysaccharide K (PSK) potentiates in vitro activation of the cytotoxic function in human blood lymphocyte by autologous tumour cells. Cancer Immunol Immunother, $35: 193.198,1992$.

35) Hayashi $C$ : Statistical study on Japanese national character. J Japan Statst Sco (Special Issue), 71-95, 1987.

36) Haysashi $C$ : Belief systems and the Japanese way of thinking : interchronological and international perspectives. In : Motoaki $\mathrm{H}$, Misumi J, Wilpert B, eds. Proceedings of 22nd International Congress of Applied Psychology. Hove, UK : Lawrence Erlbaum Associates Lid, 3 : 3-34, 1992.
Offprint requests to : $\mathrm{K}$. Ogoshi Department of Surgery, School of Medicine, Tokai University. Bohseidai Isehara, Japan 


\section{Ann Cancer Res Ther}

HLA Antigens and Postoperative Adjuvant Immunochemotherapy in Gastric Cancer ; a Multidimensional Data Analysis

p 95 99

\section{Kyoji Ogoshi}

癌治療を行う前に，効果のある，患者個人個人に最適 な治療法の予測が可能であれば，癌患者のquality of life （QOL）の向上に役立つものと考えられる。そこで，本 研究では，個人を同定出来るHLA抗原を用いて，個人個 人の治療法が予測できないかどうか検討を行った。

[対象と方法] 対象患者の術前にmicrocytotoxicity assayを用いてHLA-A，-B，-C抗原を測定した。 HLA抗 原の分類は，胃癌切除例429例を対象とし，数量化而類 ${ }^{11}$ 13)を用いて四つの型に分類した。予後因子の検討は，胃 切除術単独90例，胃切除術+化学療法98例，胃切除術+ PSK併用免疫化学療法133例を対象として, Coxの比例八 ザードモテルを用いて解析した。

[結 果] (1) 数量化四類により，1型はA-3,Aw19, Aw-33, B-12, B-44, Bw-56, B-35抗原，2型はAw31，B-5, B-51，B-13，Cw-4抗原，3型はA-2，A-9, Bw52, B-7, B-15, Bw-62, B-16, B-39, В-40, Вw-60, Bw-48, Cw-7抗原，4型はA-10，A-11，Bw-22，Bw-54, Bw-55, Bw-61, Bw-46, Bw-59, Cw-1，Cw-3抗原に分 類された（図1）。

(2) 単一予後因子としての年㱓は49歳以下の患者が最 も予後良好で，60歳以上の患者との間，進行度では， pTNM stage 1Aの患者がもっとも予後良好で, stage 2, 3A，3B，4の患者との間，治療法別では，PSK併用免疫 化学療法群がもっとも予後良好で, 胃切除群との間, HLA分類型は，3型が最も予後良好で，1型との間に有意 差を認めた（表2）.

(3)多因子での検討では，HLA抗原型4型でPSK併用 免疫化学療法施行群が最も予後良好で，1型，2型，3型 の胃切除群，1型の化学療法施行群に比し有意に予後良 好であった（表3）

[考 察] われわれは，術前のシアル酸が異常值を 示す症例，または血清IAP (immunosuppressive acidic protein）值が異常值を示し，脾铖摘出がなされた症例で は, 術後PSK併用免疫化学療法が最適な治療法であるこ とを報告した ${ }^{14,15)}$ 。一方，個人を同定出来るHLA抗原を 用いて検討を行ったところ，HLA-Bw-40抗原陽性胃癌患 者のPSK併用免疫化学療法施行例は予後良好であっ た ${ }^{32)}$ 。しかし，HLA抗原はその特徵として多様性を示す ことが知られている．そこで，本研究では，数量化正類 を用いてHLA抗原の発現頻度からHLA抗原を群として分 類し，治療法と予後を検討したところ，HLA抗原のパ ターンと治療法により予後が異なっていた。このことは HLA抗原のパターン（そのようなHLA抗原を持っている 患者）に相対する最適な治療法が存在することを示して いるものと考えられる.よって，癌患者のHLA抗原の測 定は，個人個人の最適な治療法の予測に有用であると考 えられた。
Investigation of Thymidylate Synthase Induction in Colorectal Tissues after Administration of Anticancer Drug, Fluorinated Pyrimidine Fluoride Derivatives

p 101 104

Kitaro Futami et al.

大腸癌に対してUFTならびにTegafurの術前投与を行 い，組織内 $5 F u$ 濃度およびTS阻害率を比較検討するとと もに，薬剤非投与例をコントロールとして，抗癌剤投与 による組織内TSの変動についても検討を加えた。

[対象と方法］ 大腸癌切除症例48例を对象とした。 37例は薬剤投与例（UFT投与群20例, Tegafur投与群17 例）であり，術前7日間抢のおの $600 \mathrm{mg}$ ，分 3 とし経口連 続投与を行った。手術時, 腫瘍組織，正常部粘膜，リン パ節（1群領域）を採取し，凍結保存ののち各組織にお ける5Fu濃度，TS量，TS阻害率を測定し，UFT群と Tegafur群を比較した。また，11例の薬剤非投与例につい ても各組織のTS量を測定し, 薬䯇投与群と比較した。

[結 果] 薬剂投与群における5Fu濃度の比較では 腫瘍組織においてUFT群がTefagur群に比し，有意に高值 であった。また，TS阻害率についてもUFT群で有意に高 い阻害率を示した。各組織におけるTS量については， UFT群, Tegafur群とも薬剂非投与群に比較し, 有意に高 いTS量を示し，UFT群でより顕著であった。腫瘍組織に おけるTS量とTS阻害率の関係をみると，TS量に関係な く，TS阻害率は50〜60\%の值であった。

[ 考 察] 術前 1 週間連投による組織内 $5 \mathrm{Fu}$ 濃度およ びTS阻害率の検討を行い，腫瘍組織においてUFT群で Tegafur群に比し有意に高い值を示し，大腸癌に対しても UFTが上り強い抗腫瑒効果を期待しうる因子を備えてい ると考えられた，抗癌剂による組織内TSの変動について は，腫慯組織において非投与群にくらべUFT群て3.3倍, Tegafur群で2.4倍, 正常粘膜でもおのおの3.2倍, 2.3倍の TS誘導が生じていた，しかしながら，TS量に関係なく TS阻害率は50〜60\%に留まっていた，この程度の值が䠛 床投与量におけるUFT単独投与の限界とも考えられる。

最近の知見にて，5FuとCDDPあるいはLeucovorin併用 効果のメカニズムが解明されている．5FuのDNA合成障 害に最も重要となるFdUMP-TS-met-hylen hydrofolate (Me-THF) のternary complex形成の上で不足したMeTHFがCDDP代謝過程で補れることにより，ternary complex 形成が促進され相乗効果を発揮することが証明 されている，今回のTS量が増えても，阻害率に反映しな いという秸果もその原因をMe-THF枯渴に求めることも できるが，今後TSだけでなく，Me-THFの検索が必要で あろう。

大腸癌は胃癌にくらべ，TSにより強く依存し，TS阻害 により感受性が高いとも考えられており，薬剂側因子か らみて大腸癌に対してもTegafurにくらべTSの誘導が強い UFTの効果が期待されるところである. 